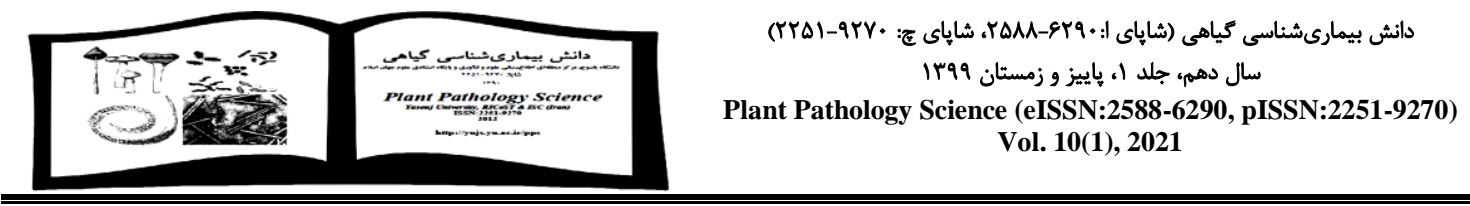

Research Article

\title{
Tomato bacterial diseases in West Azerbaijan province of Iran
}

\author{
MARYAM KHEZRI ${ }^{1 凶}$, SIMIN ALLAHYARI IGDIR ${ }^{2}$, \\ ZAHRA AGHAZADEH SOUREH ${ }^{2}$ \\ 1.Iranian Research Institute of Plant Protection, Agricultural Research, \\ Education and Extension Organization (AREEO), Tehran, Iran \\ 2.Department of Plant Protection, Faculty of Agriculture and Natural Resources, \\ Urmia University, Urmia, Iran
}

Received: 15.05.2021

Accepted: 27.07.2021

Khezri M, Allahyari Igdir S, Aghazadeh Soureh Z (2021) Tomato bacterial diseases in West Azerbaijan province of Iran. Plant Pathology Science 10(1):86-96. Doi: 10.2982/PPS.10.1.86.

\begin{abstract}
Introduction: Tomato is one of the most important and most widely consumed vegetable in the world. Tomato also is one of the most important products in West Azerbaijan Province of Iran, which plays an important role in the province's agricultural economy. Accurate bacterial disease diagnosis is the first and most important step in designation methods of disease management. Materials and Methods: Tomato farms in the suburbs of the province cities were visited and diseased plants were sampled. Bacteria were isolated and purified from patient tissues and identified based on phenotypic and molecular characteristics. The bacterial pathogenicity test was performed according to Koch principles. Results: Tomato bacterial pathogens in this province include Clavibacter michiganensis subsp. michiganensis, Xanthomonas vesicatoria, Pseudomonas syringae pv. tomato, P. syringae pv. syringae and Dickya chrysanthemi, agents of bacterial canker, bacterial spot, bacterial speck, syringe leaf spot and soft stem rot. Disease symptoms, phenotypic and molecular properties of pathogenic bacteria, previous reports on these bacteria from Iran and their distribution in different regions of West Azerbaijan Province are presented. Conclusion: These bacteria, with the exception of the tomato bacterial canker agent, are reported for the first time from West Azerbaijan province.
\end{abstract}

Key words: Stem rot, Bacterial canker, Bacterial speck, Bacterial spot

$\triangle$ Corresponding author: ma_khezri@yahoo.com 


$$
\text { مقاله يزوهشى }
$$

\section{بيمارىهاى باكتريايى گوجهفرنكى در استان آذربايجان غربى ايران}

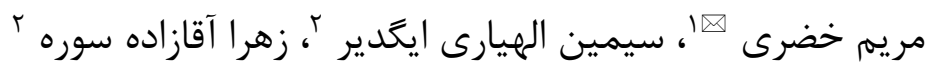

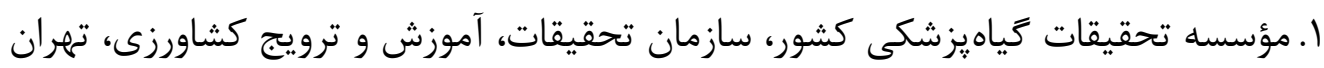

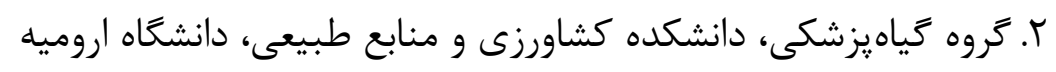

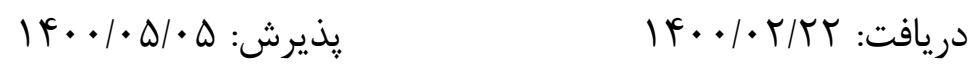

خضرى م، الهيارى ايخدير س، آقازاده سوره ز (99 (I) بيمارىهاى باكتريايى گوجهفرنكى در استان

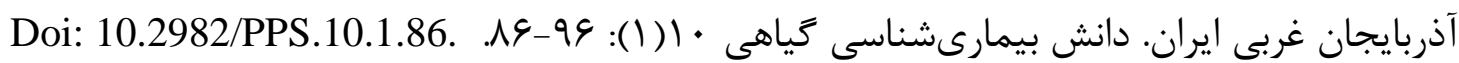

مقدمه:كوجهفرنكى يكى از مهممترين و يرمصرفترين سبزىها در جهان است. گوجهفرنكى يكى از

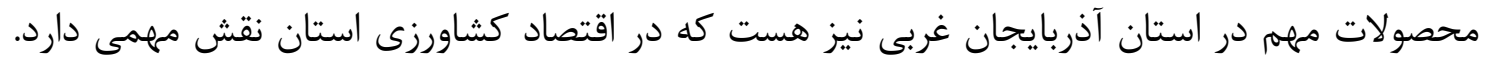

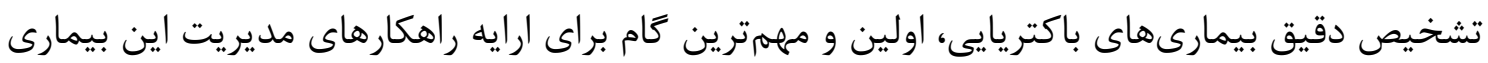
ها است. مواد و روشها: مزرعههاى گوجهفرنكى حومه شهرستانهاى اين استان بازديد شدند و از

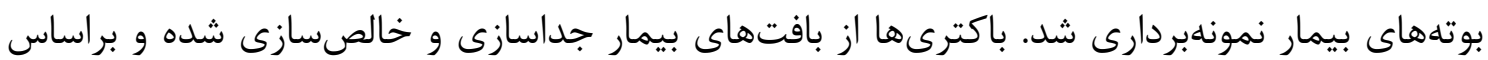

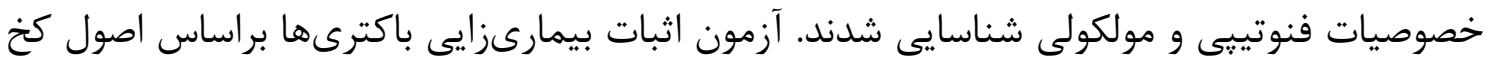
انجام شد. يافتهها: باكترىهاى بيماريزاى گوجهفرنكى در اين استان، Clavibacter michiganensis ‘Pseudomonas syringae pv. tomato ،Xanthomonas vesicatoria ،subsp. michiganensis خ Dickya chrysanthemi و P. syringae pv. syringae

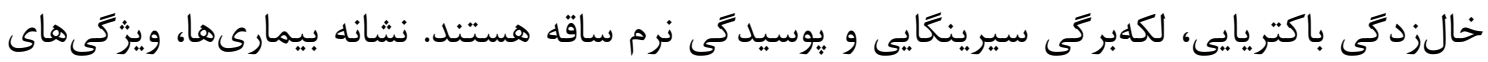

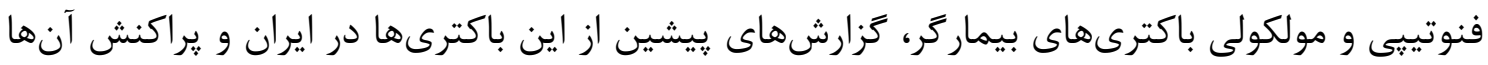

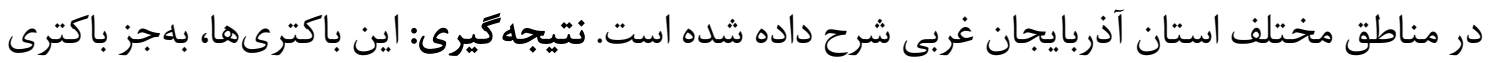

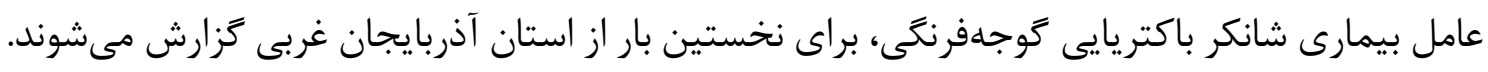
وازًٔان كليدى: يوسيدكى ساقه، شانكر باكتريايى، خالزدكى باكتريايى، لكه باكتريايى

\section{Introduction}

مقدمه

گوجهفرنكى (Solanum lycopersicum L.) بومى آمريكاى جنوبى و از گياهان عالى گل دار، دوليهاى و دييلوئيد از تيره بادمجانيان (Solanaceae) است كه در مزرعه و كلخانه، در خاك يا بسترهاى هيدوريونيك بهطور گسترده كشت مىشود (Wakil et al. 2018). اين زياه مورد حمله SV عامل بيمارىزاى گياهى قرار مى گيرد كه از اين تعداد، ها عامل باكتريايى مىباشند (Jones et al. 2014).

هويسنده مسئول ma_khezri@yahoo.com 
باكترىهاى Clavibacter michiganensis subsp. michiganensis ،Ralstonia solanacearum ، Pectobacterium g P. syringae pv. syringae ‘Pseudomonas syringae pv. tomato Borkar and Yumlembam ) باكترىهاى مهرم بيمارىزاى گوجهفرنكى هستند carotovorum .(2017, Santamaría-Hernando et al. 2019, Adhikari et al. 2020, Siddique et al. 2020 كوجهفرنكى يكى از محصولات مهم كشاورزى در استان آذربايجانغربى است كه توليد آن از اهميت زيادى برخوردار است. بيمارىهاى باكتريايى از مهمترين عوامل بيمارگر اين محصول در استان مىباشند و خسارتهاى اقتصادى قابل توجهى را به كشاورزان وارد مىسازند، بهطورى كه در برخى سال ها خسارت كمى و كيفى ناشى از آنها، موجب رها شدن مزرعه ها توسط كشاورزان منطقه مى 1al. 1994 و اين موضوع توجه به مديريت اين بيمارىها را ضرورى مىسازد. از آنجايى كه اطلاعات محدودى در مورد عوامل بيمارىزاى باكتريايى گوجهفرنغى در استان آذربايجان غربى وجود داشت، لذا

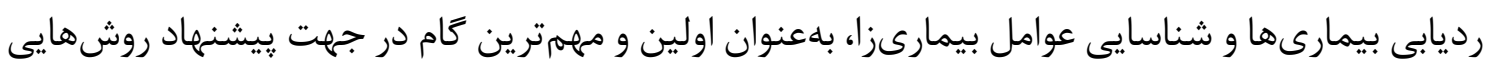
در مديريت مؤثر اين بيمارىها، ضرورى بهنظر رسيد.

\section{Materials and Methods}

مواد و روشها مزرعههاى گوجهفرنكى حومه شهرستانهاى اروميه، اشنويه، خوى، سلماس، ماكو، مهاباد، مياندوآب، نقده و بوكان در ماههاى مرداد تا اوايل مهر سالهاى 9V_M نمونهبردارى شد. پس از جداسازى و خالصسازى، بررسىهاى فنوتيبى و مولكولى جدايههاى باكترىها، آزمون اثبات بيمارىزايى آنها انجام شد. جهت اثبات اصول كخ، بوتههاى سالم گوجهفرنكى با باكترى هاى بيمارىزا مايهزنى شدند و پِ از بروز نشانه بيمارى، مجدداً باكترىها از گياهان بيمار جداسازى شدند. باكترىهاى جداسازى شده از نظر شكل، رنَ و ساير ويزگى هاى كلنى، همجنين برخى ويزگ هاى فنوتييى كليدى از قبيل رنتىآميزى گرم، تحرك، رشد هوازى/بىهوازى و اكسيداز با باكترىهاى بيمارىزاى اوليه مقايسه شدند. نشانه بيمارىها، ويزگى هاى فنوتييى و مولكولى جدايههاى باكتريهاى بيمارىزا، همجنين سابقه گزارش اين بيمارىها در ايران و :يراكنش آنها در استان آذربايجان غربى شرح داده شده است.

\section{Results and Discussion}

ينج بيمارى باكتريايى روى گوجهفرنكى در اين استان به اين شرح شناسايى شدند:

ا. بيمارى شانكر باكتريايى گوجهفرنكى (Tomato bacterial canker disease) نشانه بيمارى: يزمردگى يكطرفه بركها و نكروز حاشيه برگجهها از نشانه اين بيمارى است كه با 
كسترش بيمارى به رنت زرد تا قهوهاى درمىآيند (شكل (، B و C). روى ساقهها لكههاى قهوهاى ايجاد مىشود كه با حذشت زمان ترك خورده و شانكرها تشكيل مىشوند (شكل I، A و C). ركههاى زرد روشن تا قهوهاى در داخل بافتهاى آوندى ايجاد شده كه اين گونه تغيير رنغ در محل گرهها بسيار مشخص است. با كسترش و سيستميك شدن بيمارى در زياه، در حركت آب در آوندهاى جوبى اختلال ايجاد شده كه نتيجه آن بروز نشانه يرمرد كوجֶى با مركز قهوهاى سوخته و برآمده است كه هاله سفيد رنگ مات در اطراف آنها تشكيل مىشود

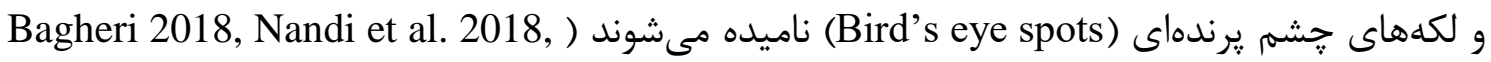
Aghazadeh ( Siddique et al. 2020 (نانه روى ميوه، در بازديدهاى انجام شده بdندرت مشاهده شد). خصوصيات فنوتيبى و مولكولى جدايههاى باكترى: تمامى سويههاى باكترى گرم مثبت، هوازى اجبارى، كاتالاز مثبت و اكسيداز منفى بودند. باكترىها ميلهاى شكل و بدون تحرك بوده و روى محيط كشت
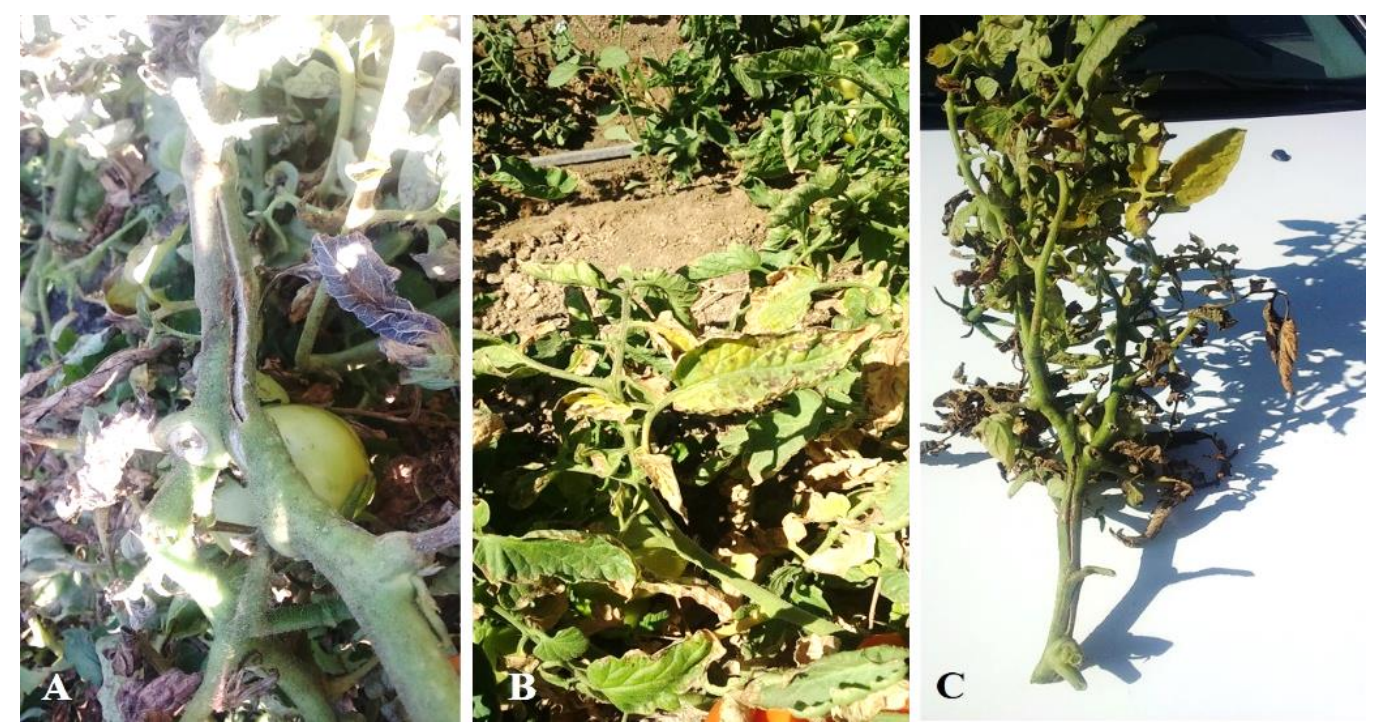

شكل ا. نشانه بيمارى شانكر باكتريايى گوجهفرنگى: A.شانكر روى ساقه، B. لكههاى نكروز روى بركها،

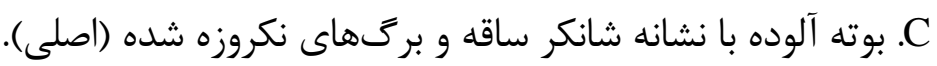

Figure 1. Symptoms of tomato bacterial canker disease: A. Canker on stem, B. Necrotic spots on leaves, C. Infected plant with canker on stem and necrotic leaves (Original). 
به رنت زرد تا نارنجى بودند. كليه سويهها قادر به (yeast extract dextrose-CaCO 3 medium= YDC ) رشد روى محيطهاى كشت (2,3,5-triphenyl- tetrazolimn chloride medium=TTC) و بودند و روى برى گياهان توتون و لاله (Corynebacterium nebraskense semi-selective medium) عباسى ايجاد واكنش فوقحساسيت كردند. نتايج آزمونهاى هيدروليز اسكولين، فسفاتاز، توليد ״ِيتون و لستيناز مثبت و نتايج آزمونهاى آرزنين دهيدرولاز، احياء نيترات، اورهآز، هيدروليز نشاسته،

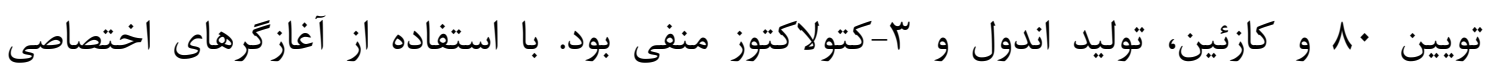
(Burokiene 2006) CMM5/CMM6 قطعات \& ا و و • جV جفتبازى تكثير شدند. بر اساس نتايج آزمونهاى فنوتييى و مولكولى، عامل بيمارى باكترى C. michiganensis subsp. michiganensis تشخيص داده شد. كزارشهاى بيشين بيمارى در ايران: اين بيمارى، اولين بار در ايران از يك مزرعه گوجهفرنكى در حومه

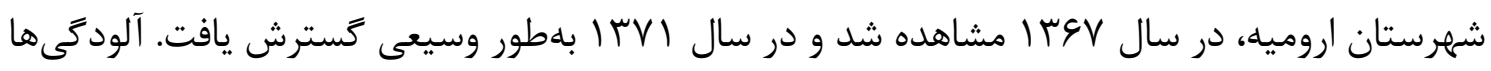
علاوه بر مزرعههاى گوجهفرنكى اروميه، از مهاباد و اشنويه نيز گزارش شده است ( Mazarei et al. 1994). در سالهاى بعد گزارشهاى ديخرى از اين بيمارى از استان آذربايجان غربى منتشر شد ( Nazari et al. 2008, Osdaghi et al. 2018 (اين بيمارى از برخى از مناطق كشت گوجهفرنكى در استانهاى كلستان، زنجان و آذربايجان شرقى نيز گزارش شده است ( Mohammadi-Pour and Rahimian 1998,

(Nazari et al. 2008, Osdaghi et al. 2018 يراكنش بيمارى در استان آذربايجان غربى: عامل بيمارى شانكر باكتريايى از برخى از مزرعههاى Fوجهفرنغى در اروميه، خوى و مياندوآب جداسازى شده است ( Aghazadeh Soureh ) .(Aghazadeh Soureh et al. 2017،2018

r. بيمارى لكه باكتريايى گوجهفرنگى (Tomato bacterial spot disease) نشانه بيمارى: ايجاد لكههاى نكروزه در برى، ميوه، گل و ساقه از مشخصترين نشانه اين بيمارى است. لكههاى روى برى ممكن است با يك هاله زرد رنگ احاطه شده باشند (شكل r، A). لكهها اغلب در حاشيه يا نوك برگ قرار دارند و اندازه آنها به سه تا پنج ميلىمتر مىرسد. اگر تعداد لكههاى روى برى زياد باشد، برىها زرد شده و ريزش مى كنند. نشانه اوليه روى ميوه، لكههاى كوجى و برجسته، به رنى قهوهاى تيره تا سياه است و همانند لكههاى جشم يرندهاى در بيمارى شانكر باكتريايى داراى هاله سفيدرنگ هستند. برخلاف بيمارى شانكر باكتريايى، با افزايش سن ميوه، هاله سفيد رفته رفته محو مىشود (Borkar and Yumlembam 2017, Adhikari et al. 2020). 
خصوصيات فنوتييى و مولكولى جدايههاى باكترى: جدايهها كرم منفى، هوازى اجبارى، ميلهاىشكل و متحرك بودند. پر كنههاى باكترى روى محيط كشت YDC محدب و به رنگ زرد بودند. واكنش جدايهها به آزمونهاى اكسيداز، يكتيناز، آرزنين دهيدرولاز، توليد رنحدانه فلورسنت روى محيط كشت KB (King’B medium)، توليد r-كتولاكتوز، اورهآز و لستيناز منفى و در آزمونهاى كاتالاز، واكنش فوقحساسيت روى بركهاى توتون، هيدروليز نشاسته، آرزنين، كازئين و تويين • ^ مثبت بود. با استفاده از آغازگرهاى اختصاصى XV1F/ XV1R (Beran and Mráz 2013)، قطعه ه هب جفتبازى در سويههاى مورد مطالعه تكثير شد. بر اساس نتايج آزمونهاى فنوتييى و مولكولى، عامل بيمارى باكترى Xanthomonas vesicatoria كزارشهاى پيشين بيمارى در ايران: بيمارى لكه باكتريايى گوجهفرنكى، اولين بار در سال ^عبا از مناطق جنوب كشور (Bahar 1992) گزارش شده است. باكترى X. euvesicatoria pv. euvesicatoria در مناطق محدودى از ايران و سويههاى X. euvesicatoria pv. perforans نيز از استانهاى شمالى و شمال غربى گزارش شده است (Osdaghi et al. 2017). يراكنش بيمارى در استان آذربايجان غربى: باكترى Xesicatoria بهعنوان عامل بيمارى لكه باكتريايى كوجهفرنكى، براى اولين بار از استان آذربايجان غربى و ايران گزارش شد. اين باكترى از برخى از Allahyari ( مزرعهاى گوجهفرنكى در شهرستانهاى اشنويه، خوى، ماكو و نقده نيز گزارش شده است .(Igdir 2018

\section{r. بيمارى خالزدگى باكتريايى گوجهفرنگى (Tomato bacterial speck disease)} نشانه بيمارى: مهمترين نشانه بيمارى وجود لكههاى نكروزه روى برك، ساقه و ميوه است. اين لكههاى روى برگ، در ابتدا قهوهاى تا سياه، كوجى با هاله زرد رنگ است و بهصورت يراكنده در يهنك برگها و بيشتر در حاشيه آنها ديده مىشوند (شكل r، A). در اثر بههم ييوستن لكهها، ناحيه وسيعى از بافت برى نابود شده كه موجب مرى و ريزش آن مىشود. لكههاى روى دمبرگ، كاسبرگ، دمگل و ساقه بيضوى تا كشيده مىباشند. لكههاى روى ميوه سياه و كمى برآمده بوده و داراى هاله باريك سبز تا زرد هستند. در ميوههاى نارس لكهها سطحى هستند اما در ميوههاى رسيده حالت فرورفته دارند. تنها ميوههاى نارس با قطر كمتر از سه سانتىمتر به بيمارى حساس هستند. آلودگى ميوه ممكن است منجر

به آلودگى بذرها شود (Borkar and Yumlembam 2017, Santamaría-Hernando et al. 2019). خصوصيات فنوتييى و مولكولى جدايههاى باكترى: اين جدايهها گرم منفى، ميلهاى شكل، هوازى، كاتالاز مثبت و متحرك بودند. واكنشهاى اكسيداز، پيكتيناز و آرزنين دىهيدروزناز، احياء نيترات، متيل رد،

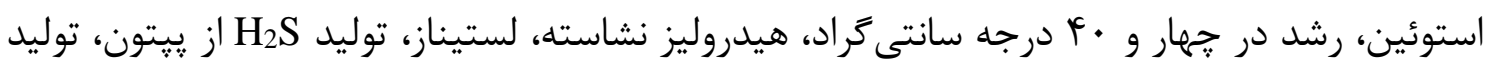


كاز از كلوكز و توليد ب-كتولاكتوز منفى و واكنشهاى فوق حساسيت روى برك هاى توتون، هيدروليز

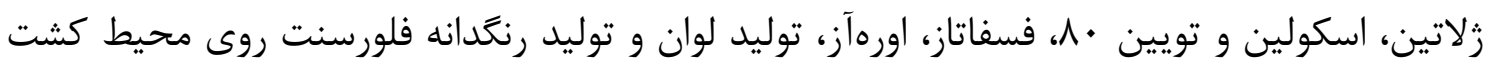

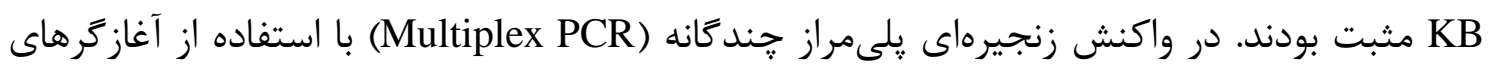

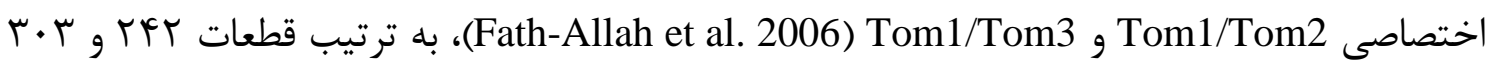
جفتبازى در سويههاى مورد مطالعه، تكثير شد. بر اساس نتايج آزمونهاى فنوتييى و مولكولى، عامل بيمارى باكترى P. syringae pv. tomato

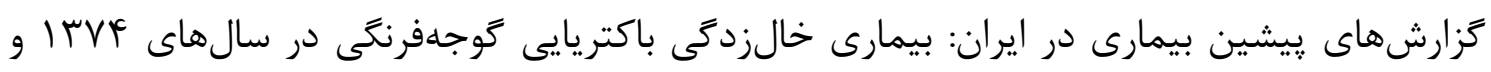

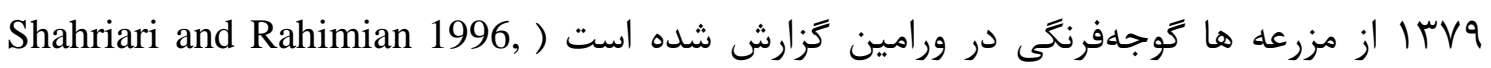
(Ghobakhloo and Rahimain 2000 يراكنش بيمارى در استان آذربايجان غربى: باكترى عامل بيمارى خالزدمى باكتريايى، از برخى از

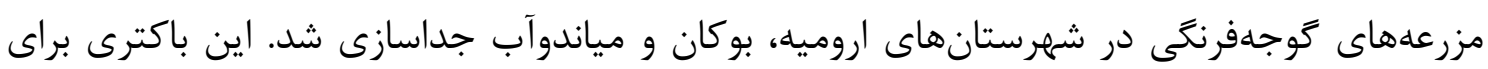
اولين بار از استان آذربايجان غربى كزارش مىشود (Allahyari et al. 2017, Allahyari Igdir 2018).

\section{f. بيمارى لكهبركى سيرينكايى گوجهفرنكى (Tomato syringae leaf spot disease)}

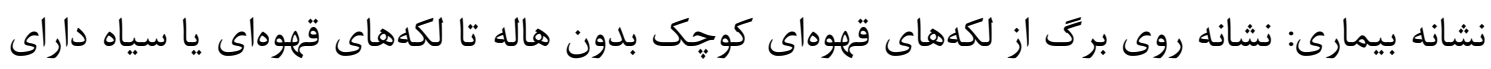
هاله زرد متفاوت است (شكل r، A و B). لكههاى روى برك در اين بيمارى شبيه لكههاى ايجاد شده

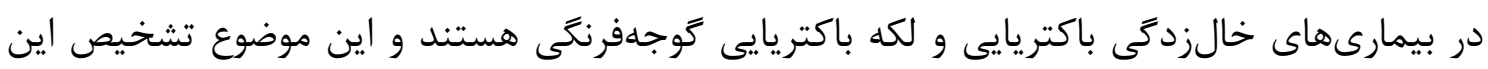

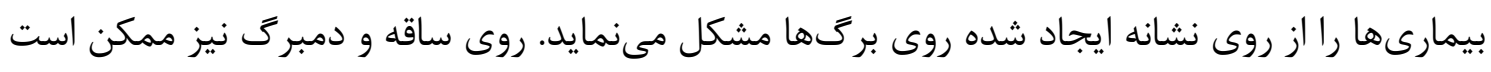

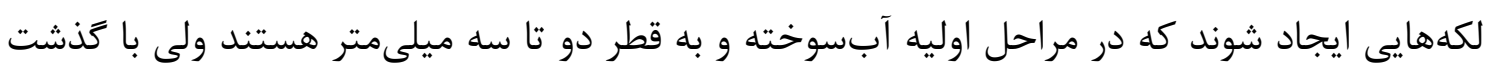

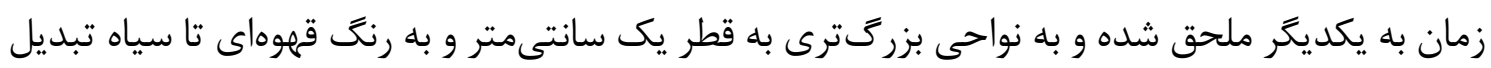
مىشوند (Garibaldi et al. 2007). خصوصيات فنوتييى و مولكولى جدايههاى باكترى: جدايههاى باكترى ترم منفى، ميلهاى شكل و هوازى

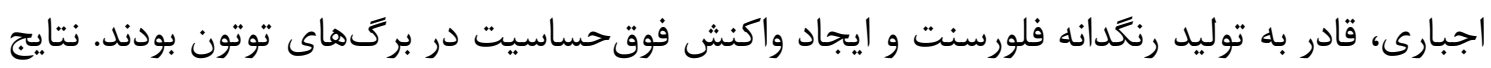

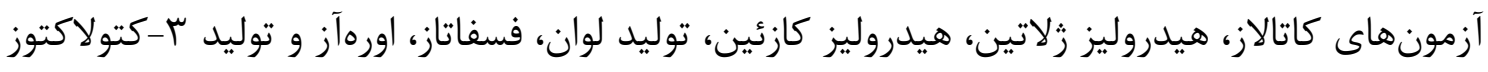

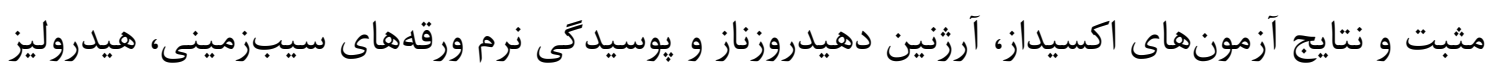

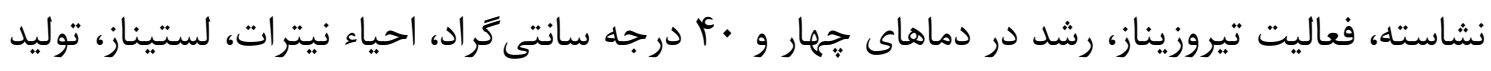

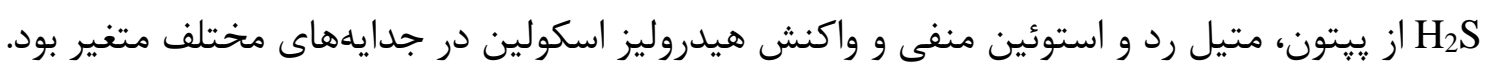




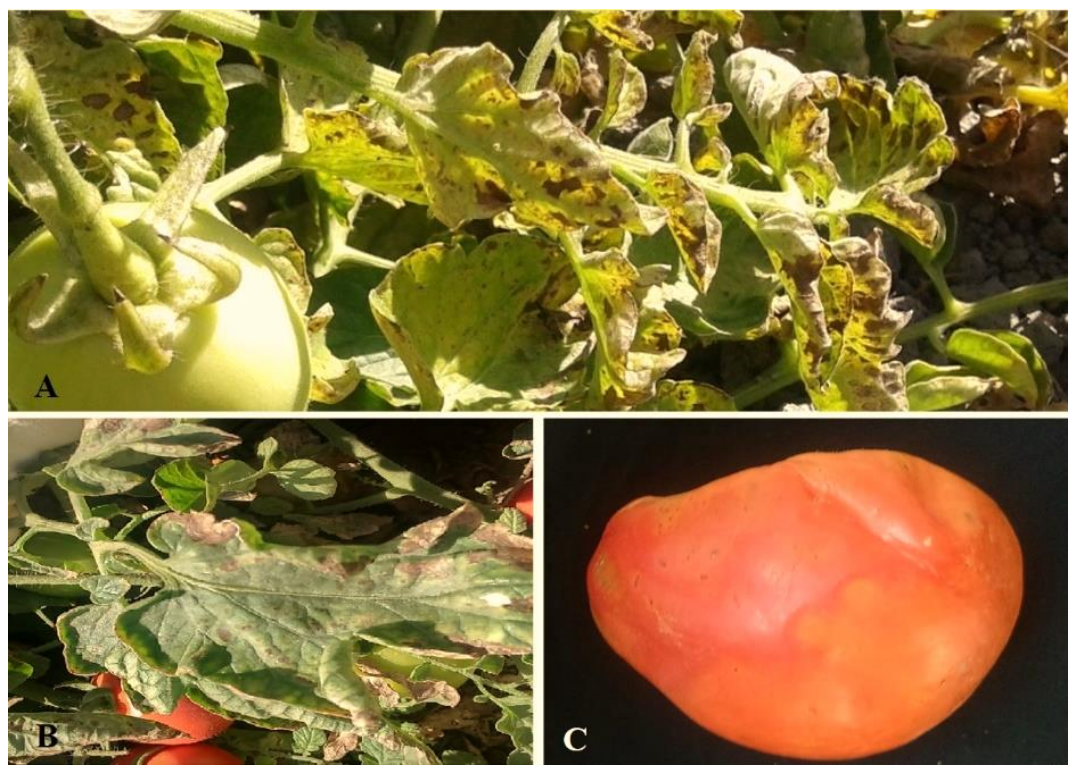

شكل r. A. لكههاى نكروزه با هاله زرد رنگ در اطراف آنها روى برگها، B. لكههاى نكروزه فاقد هاله

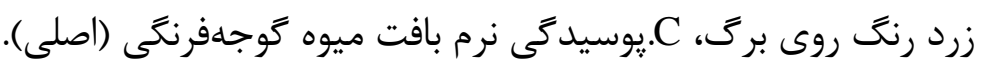

Figure 2. A .Necrotic spots with yellow halo around them on the leaves, B. Necrotic spots without yellow halo on leaf, C. Soft rot symptoms in tomato fruit tissue (Original).

در واكنش زنجيرهاى يلىمراز جندكانه با استفاده از آغازگرهاى اختصاصى Tom1/Tom2 و Fath-Allah et al. 2006) Tom1/Tom3)، فقط قطعه ץ.ץ جفتبازى مربوط به جفت آغازگر Tom1/Tom3 در سويههاى مورد مطالعه، تكثير شد. بر اساس نتايج آزمونهاى فنوتييى و مولكولى، عامل بيمارى باكترى Pyringae pv. syringae تشخيص داده شد.

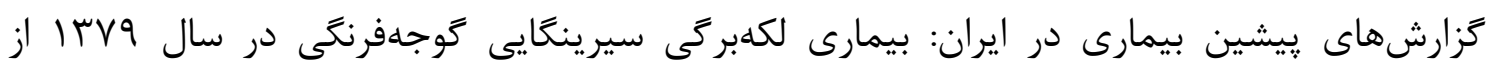
مزرعههاى گوجهفرنخى در ورامين گزارش شده است (Ghobakhloo and Rahimain 2000). يراكنش بيمارى در استان آذربايجان غربى: اين اولين گزارش از وجود باكترى در استان آذربايجان غربى است. باكترى لكهبركى سيرينَايى از برخى از مزرعه ها گوجهفرنكى در شهرستانهاى اشنويه، خوى و نقده جداسازى شد (Allahyari et al. 2017, Allahyari Igdir 2018).

\section{ه. هيمارى هوسيدگى نرم ساقه گوجهفرنكى (Tomato stem soft rot disease)} نشانه بيمارى: روى سطح بيرونى ساقه و گاهى اوقات بخشهاى داخلى آن لكههاى قهوهاى ايجاد مى شود كه يس از مدتى در اين نواحى يوسيدگى نرم و لهيده شدن بافت مشاهده مىشود. مغز ساقه معمولاً تجزيه شده و سبب توخالى شدن ساقه مىشود. با تخريب ساقه عملكرد آن بهويزه انتقال آب و مواد غذايى دجار اختلال شده و منجر به بروز نشانه يزمردگى و زرد شدن برگها بهويزه در مواقع گرم روز 
مىشود. نشانه روى ميوه به صورت يوسيدگى هاى نرم و لزج است و سرانجام ميوه به توده آبكى با يوست

نازك تبديل مىشود (شكل r، C) (Ngadze et al. 2012, Borkar and Yumlembam, 2017). خصوصيات فنوتييى و مولكولى جدايههاى باكترى: جدايههاى مورد مطالعه گرم منفى، ميلهاى شكل و بى هوازى اختيارى بودند. همه جدايهها قادر به ايجاد بوسيدكى نرم در ورقههاى سيبزمينى بودند. نتايج آزمونهاى اكسيداز، فوقحساسيت روى توتون، آرثنين دهيدرولاز، توليد رنگدانه فلورسنت، هيدروليز نشاسته، فسفاتاز، متيل رد و توليد كاز از كلوكز منفى و نتايج آزمونهاى كاتالاز، هيدروليز زلاتين، كازئين و اسكولين، احياء نيترات، لستيناز، رشد روى محيط كشت Nutrient agar) NA حاوى Y-V درصد كلريد سديم و توليد HDE1/ADE2 ازيتون مثبت بود. با استفاده از آغازگرهاى اختصاصى (Nassar et al. 1996)، قطعه • Fr جفتبازى در سويههاى مورد مطالعه، تكثير شد. بر اساس نتايج آزمونهاى فنوتييى و مولكولى، عامل بيمارى باكترى Dickya chrysanthemi تشخيص داده شد. كزارشهاى ييشين بيمارى در ايران: در ايران اين باكترى تاكنون از روى گَجهفرنكى گزارش نشده است و اين اولين زَارش مىباشد. يراكنش بيمارى در استان آذربايجان غربى: اين باكترى از برخى از مزرعههاى گوجهفرنكى در شهرستانهاى اروميه، سلماس، مهاباد و مياندوآب نيز جداسازى شده است (Allahyari Igdir 2018).

\section{Conclusion}

باكترىهاى P. syringae pv. tomato XX. vesicatoria CC. michiganensis subsp. michiganensis P. Chrysanthemi و P. chringae pv. syringae خالزدگى باكتريايى، لكهبرگى سيرينگايى و يوسيدگى نرم ساقه از مزرعههاى گوجهفرنكى نواحى مختلف استان آذربايجان غربى گزارش شدهاند. با توجه به بذرزاد بودن جهار باكترى اول، لزوم تهيه بذر سالم و تواهى شده از مهمترين راهكارهاى مديريت اين بيماريها است. بررسى روشهاى زراعى، مهار زيستى و شيميايى براى مديريت اين بيمارىها يِيشنهاد مىشوند.

\section{References}

Adhikari P, Adhikari TB, Louws FJ, Panthee DR (2020) Advances and challenges in bacterial spot resistance breeding in tomato (Solanum lycopersicum L.). International Journal of Molecular Sciences 21:1734.

Aghazadeh Soureh Z (2018) Phenotypic and genotypic identification of tomato pathogenic bacteria in Urmia. M.Sc. Thesis, Urmia University, Urmia, Iran. (In Persian with English Abstract).

Aghazadeh Soureh Z, Khezri M, Sadeghinasab F (2017) Identification of pathogenic bacteria in tomato fields of Urmia. Proceedings of $1^{\text {st }}$ International and $5^{\text {th }}$ National 
Congress on Organic vs. Conventional Agriculture. University of Mohaghegh Ardabili, Ardabil, Iran, p.278.

Allahyari Igdir S (2018) Study on pathogenic gram-negative bacteria of tomato foliage in West Azarbaijan province. M.Sc. Thesis, Urmia University, Urmia, Iran. (In Persian with English Abstract).

Allahyari S, Khezri M, Sadeghinasab F (2017) A study on tomato gram-negative pathogenic bacteria in West Azarbaijan. Proceedings of $1^{\text {st }}$ International and $5^{\text {th }}$ National Congress on Organic vs. Conventional Agriculture. University of Mohaghegh Ardabili, Ardabil, Iran, p.279.

Bagheri A (2018) Bacterial canker of tomato. Plant Pathology Science 7:14-21. (In Persian with English Abstract).

Bahar M (1992) Identification of tomato leaf spot agent. Proceedings of $9^{\text {th }}$ Iranian Plant Protection Congress, Mashhad, Iran, p.143. (In Persian with English Abstract).

Beran P, Mráz I (2013) Species-specific PCR primers for detection of Xanthomonas vesicatoria. Crop Protection 43:213-215.

Borkar S, Yumlembam R (2017) Bacterial Diseases of Crop Plants. Boca Raton: CRC Press, 594p.

Burokiene D (2006) Early detection of Clavibacter michiganensis subsp. michiganensis in tomato. Agronomy Research 4:151-154.

Fath-Allah MM, Ali MH, Rasmi MR (2006) Using hrpl gene specific primers to detect Pseudomonas syringae pv. tomato by polymerase chain reaction. The Egyptian Journal of Experimental Biology 2:7-13.

Garibaldi A, Minuto A, Scortichini M, Gullino ML (2007) First report of syringae leaf spot caused by Pseudomonas syringae pv. syringae on tomato in Italy. Plant Disease 91:1518.

Ghobakhloo A, Rahimian H (2000) Etiology of bacterial leaf spot of tomato in Varamin. Iranian Journal of Plant Pathology 36:329-342. (In Persian with English Abstract).

Jones JB, Zitter TA, Momol TM, Miller SA (2014) Compendium of Tomato Diseases. St. Paul, MN: APS Press, 168p.

Mazarei M, Orumchi S, Lora C (1994) Investigation of bacterial canker of tomato in West Azarbaijan. Proceedings of $11^{\text {th }}$ Iranian Plant Protection Congress, Karaj, Iran, p.160. (In Persian with English Abstract).

Mohammadi-Pour M and Rahimian H (1998) Characteristic of the strains of Clavibacter michiganensis subsp. michiganensis inciting bacterial canker of tomato in East Azarbaijan. Proceedings of $13^{\text {th }}$ Iranian Plant Protection Congress, Karaj, Iran, p.187. (In Persian with English Abstract).

Nandi M, MacDonald J, Liu P, Weselowski B, Yuan ZC (2018) Clavibacter 
michiganensis ssp. michiganensis: bacterial canker of tomato, molecular interactions and disease management. Molecular Plant Pathology 19:2036-2050.

Nassar A, Darrasse A, Lemattre M, Kotoujansky A, Dervin C, Vedel R, Bertheau Y (1996) Characterization of Erwinia chrysanthemi by pectinolytic isozyme polymorphism and restriction fragment length polymorphism analysis of PCRamplified fragments of pel genes. Applied and Environmental Microbiology 62:2228-2235.

Nazari F, Niknam GR, Ghasemi A, Torabi S, Taghavi SM (2008) Phenotypic and protein profile diversity of tomato bacterial canker in Golestan and West Azarbaijan Provinces. Applied Entomology and Phytopathology 76:135-151. (In Persian with English Abstract).

Ngadze E, Brady CL, Coutinho TA, Van der Waals JE (2012) Pectinolytic bacteria associated with potato soft rot and blackleg in South Africa and Zimbabwe. European Journal of Plant Pathology 134:533-549.

Osdaghi E, Ansari M, Taghavi SM, Zarei S, Koebnik R, Lamichhane JR (2018) Pathogenicity and phylogenetic analysis of Clavibacter michiganensis strains associated with tomato plants in Iran. Plant Pathology 67:957-970.

Osdaghi E, Taghavi SM, Hamzehzarghani H, Fazliarab A, Lamichhane JR (2017) Monitoring the occurrence of tomato bacterial spot and range of the causal agent Xanthomonas perforans in Iran. Plant Pathology 66:990-1002.

Pastrik KH, Rainey FA (1999) Identification and differentiation of Clavibacter michiganensis subspecies by polymerase chain reaction-based techniques. Journal of Phytopathology 147:687-693.

Santamaría-Hernando S, Senovilla M, González-Mula A, Martínez-García PM, Nebreda S, Rodríguez-Palenzuela P, López-Solanilla E, Rodríguez-Herva JJ (2019) The Pseudomonas syringae pv. tomato DC3000 PSPTO_0820 multidrug transporter is involved in resistance to plant antimicrobials and bacterial survival during tomato plant infection. PLoS One 25:14(6): e0218815.

Shahriari D, Rahimian H (1996) Bacteria speck of tomato in Iran. Proceedings of $12^{\text {th }}$ Iranian Plant Protection Congress, Karaj, Iran, p.168. (In Persian with English Abstract).

Siddique M, Din N, Ahmad M, Ali A, Naz I, Alam SS, Ullah N (2020) Bioefficacy of some aqueous phytoextracts against Clavibacter michiganensis subsp.

michiganensis (Smith), the cause of bacterial canker of tomato. Gesunde Pflanzen 72:207-217.

Wakil W, Brust EB, Perring TM (2018) Tomato and Management of Associated Arthropod Pests: Past, Present, and Future. Pp.3-12. In: W Wakil, EB Brust, TM Perring (eds.). Sustainable Management of Arthropod Pests of Tomato, Academic Press. 